\title{
Al-Chizan
}

ISSN 1907-0985, E ISSN 2442-8256

Vol. 15, No. 2, 2019, h. 316-341

DOI: https://doi.org/10.30603/am.v15i2.1395

\section{Kelalaian Pencatatan Nikah Pada Perkawinan di Bawah Umur di Kabupaten Gorontalo}

\author{
Yunus I. M. Umar \\ KUA Kecamatan Telaga Biru Kabupaten Gorontalo \\ Email: yunusumar1983@gmail.com
}

\begin{abstract}
Marriage registration is important in marriages in Indonesia because it can have legal consequences for those who carry out marriages. This study discusses the form of negligence of marriage registration in underage marriages in Gorontalo District and the legal consequences that occur due to negligence of marriage registration in age marriages in Gorontalo Regency. This research is a field research with a juridical and sociological approach. The collection of data in the form of observations at the study site, interviews with employees of the Office of Religious Affairs, parents and underage marriages with 182 respondents, as well as literature review. The results showed: First, the form of negligence in the registration of marriages in Gorontalo Regency, namely the negligence of parents, the negligence of children and the negligence of marriage registration officers; Second, due to the legal consequences caused by negligence in registering underage marriages in Gorontalo District, namely the legality of child marriages, divorce is easy, rejection of marriage dispensation, repeating the marriage contract and marriage without the presence of government officials.
\end{abstract}

Keywords: Marriage Registration, Underage Marriage, Religious Affairs Office

\section{Negligence of Marriage Registration in Underage Marriage in Gorontalo Regency}

\begin{abstract}
Abstrak: Pencatatan perkawinan menjadi sesuatu hal yang penting dalam perkawinan di Indonesia dikarenakan dapat menimbulkan akibat hukum kepada pihak-pihak yang melaksanakan perkawinan. Penelitian ini mendiskusikan tentang bentuk kelalaian pencatatan nikah pada perkawinan di bawah umur di Kabupaten Gorontalo dan akibat hukum yang terjadi akibat adanya kelalaian pencatatan nikah pada perkawinan umur di Kabupaten Gorontalo, Penelitian ini adalah penelitian lapangan dengan menggunakan pendekatan yuridis dan sosiologis. Pengumpulan datanya berupa pengamatan di lokasi penelitian, wawancara dengan para pegawai Kantor Urusan Agama, para orangtua dan pelaku pernikahan di bawah umur dengan jumlah 250 responden, serta kajian kepustakaan. Hasil penelitian menunjukkan: Pertama, bentuk kelalaian pencatatan perkawinan di Kabupaten Gorontalo, yaitu adanya kelalaian orang tua, adanya kelalaian anak dan adanya kelalaian petugas pencatat nikah; Kedua, akibat hukum yang ditimbulkan karena kelalaian pencatatan nikah di bawah umur di Kabupaten Gorontalo, yaitu legalitas anak hasil perkawinan, mudahnya terjadi perceraian, penolakan dispensasi nikah, pengulangan akad nikah dan perkawinan tanpa kehadiran aparat pemerintah.
\end{abstract}

Kata Kunci: Pencatatan Nikah, Pernikahan di Bawah Umur, Kantor Urusan Agama 


\section{Kelalaian Pencatatan Nikah Pada Perkawinan di Bawah Umur}

di Kabupaten Gorontalo

\section{A. Pendahuluan}

Konsep perkawinan dalam Islam merupakan momen yang sangat penting dan bersejarah dalam perjalanan hidup manusia. Perkawinan akan mampu merubah status kedua belah pihak yang terlibat didalamnya, yang sebelumnya hidup terpisah dan memiliki kehidupan masing-masing-masing, namun dengan terjadinya perkawinan kedua insan ini dipersatukan dalam satu ikatan yang sama yang setelahnya masingmasing diberikan beban dan tanggung jawab sesuai dengan peranan yang diberikan oleh ajaran Islam sesuai dengan kodratnya. Tanggungjawab dan beban itulah sesungguhnya bukanlah sesuatu yang mudah dilaksanakan, ada banyak tantangan dan hambatan yang harus dilalui oleh setiap insan yang akan menjalaninya. Oleh sebab itu mereka yang telah memilih untuk menjalani ikatan perkawinan sudah seharusnya sanggup memikul dan melaksanakannya.

Syariat Islam mengatur hidup berpasangan dengan melalui jenjang perkawinan yang ketentuannya dirumuskan dengan wujud aturan-aturan yang disebut sebagai hukum perkawinan dalam Islam. Dengan demikian perkawinan bertujuan untuk membentuk suatu kehidupan rumah tangga yang harmonis rukun damai dan sejahtera. Hal ini sebagaimana telah dijelaskan dalam Undang-Undang Nomor 1 Tahun 1974 tentang Perkawinan (UUP):

Perkawinan adalah ikatan lahir batin antara seorang pria dengan seorang wanita sebagai suami isteri dengan tujuan membentuk keluarga, rumah tangga yang bahagia dan kekal berdasarkan Ketuhanan Yang Maha Esa.

Perkawinan sebagai sebuah lembaga yang menyatukan dua orang yang berbeda, baik latar belakangnya, sifat-sifatnya, keinginan-keinginannya dan kebutuhankebutuhannya menjadikan rumah tangga sebagai wadah bagi kedua orang yang baru menikah untuk dapat saling menyesuaikan diri dengan baik. Dengan menikah seseorang tidak hanya harus menyesuaikan diri dengan pasangannya, tetapi juga harus mampu menyesuaikan diri dengan perubahan-perubahan yang dialami dirinya sendiri. ${ }^{2}$

\footnotetext{
${ }^{1}$ Republik Indonesia, Undang-Undang Nomor 1 Tahun 1974 tentang Perkawinan, Pasal 1; Undang-undang ini telah diamandemen dengan Republik Indonesia, Undang-Undang Nomor 16 Tahun 2019 tentang Perubahan Atas Undang-Undang Nomor 1 Tahun 1974 tentang Perkawinan.

${ }^{2}$ Departemen Agama RI, Tuntunan Keluarga Sakinah Bagi Remaja Usia Nikah (Seri Psikologi) (Direktorat Jenderal Bimas Islam Direktorat Urais dan Pembinaan Syariah : Jakarta Tahun 2007), 119.
} 
Perkawinan merupakan awal perjuangan untuk menempuh hidup berumah tangga sekaligus mengandung ujian apakah pernikahan itu akan kokoh sepanjang hayat atau kandas ditengah samudra kehidupan. Pernikahan merupakan bukti dari kata cinta yang pernah diikrarkan yang pada gilirannya menghasilkan ketentraman rohani dan ketahanan jasmani. Pernikahan merupakan titik kulminasi janji setia yang akan diikuti dengan rasa tanggung jawab, saling menghormati demi keutuhan dan kebahagiaan rumah tangga. ${ }^{3}$

Perkawinan semacam ini diharapkan melahirkan ikatan pernikahan yang dapat mencegah perbuatan yang dilarang, seperti berzina, kekerasan fisik maupun psikis. Perkawinan dengan memegang prinsip-prinsip ideal perkawinan menumbuhkan sifat kasih sayang sejati, mewujudkan sifat ta'awun, tanggungjawab dan dapat memperkokoh silaturahmi, baik internal keluarga maupun eksternal masyarakat serta menjadi sarana melestarikan keturunan eksistensi manusia. ${ }^{4}$

Salah satu perkawinan yang sering menimbulkan permasalahan di dalam masyarakat adalah perkawinan di bawah umur, selain karena rentan terjadi perceraian, kekerasan dalam rumah tangga, kemiskinan, meningkatkan angka pengangguran dan putus sekolah, juga banyak menimbulkan permasalahan pada proses pelaksanaan perkawinannya, seperti proses administrasi perkawinan, dalam hal ini tentang pencatatan nikah yang dilakukan oleh pihak berwenang Petugas Pencatat Nikah (PPN) di Kantor Urusan Agama (KUA) Kecamatan.

Pencatatan perkawinan menurut hukum Islam secara langsung tidak dijelaskan dalam Alquran dan hadis, namun pencatatan perkawinan merupakan bagian dari administrasi negara dalam rangka mewujudkan tata kelola pemerintahan yang baik (good governance). Good governance diartikan sebagai aspek fungsional pemerintah yang efektif dan efisien dalam pelaksanaan tugasnya untuk mewujudkan tujuan nasional. ${ }^{5}$ Persoalan perkawinan di Indonesia telah memiliki aturan hukum nasional

${ }^{3}$ Tim Perumus, Pohutu Aadati Lo Hulondalo Tata Upacara Adat Gorontalo, Hasil Seminar Adat Gorontalo 2007 (Gorontalo: Pemerintah Daerah Kabupaten Gorontalo, Forum Pengkajian Islam AlKautsar Gorontalo, Tokoh Adat U Duluwo Limo Lo Pohalaa Gorontalo dan Tim Akademisi Gorontalo, 2008), 128.

${ }^{4}$ Yusdani, Menuju Fiqh Keluarga Progresif(Yogyakarta: Kaukaba Dipantara, 2015), 183.

${ }^{5}$ Rifdan dan Muhammadong, Tata Kelola Pencatatan Perkawinan Berdasarkan Undang-Undang (Makassar: Badan Penerbit UNM, 2017), 3. 
yang telah berlaku bagi seluruh wilayah Indonesia, yaitu Undang-Undang Nomor 1 Tahun 1974 tentang Perkawinan.

Pencatatan perkawinan menurut hukum negara dibuktikan dengan adanya akta nikah atau buku nikah. Sedangkan dalam hukum Islam, pencatatan diwajibkan dalam hal perdagangan, namun kaitannya dengan perkawinan adalah hubungan manusia dengan manusia, sehingga metode ushul fikih yang digunakan adalah maslahah mursalah. Hal ini karena meski secara formal tidak ada ketentuan ayat atau sunnah yang memerintahkan pencatatan, namun kandungan maslahatnya sejalan dengan tindakan syara yang ingin mewujudkan kemaslahatan bagi manusia. Dengan kata lain, pencatatan perkawinan merupakan ketentuan yang perlu diterima dan dilaksanakan oleh semua pihak. ${ }^{6}$ Sebagaimana aturan dalam pasal 2 ayat 2 UUP bahwa tiap-tiap perkawinan dicatat menurut peraturan perundang-undangan yang berlaku. ${ }^{7}$

Atas dasar inilah apabila seseorang ingin melakukan perkawinan, maka dicatat menurut peraturan perundang-undangan yang berlaku dengan tujuan untuk mewujudkan ketertiban perkawinan dalam masyarakat. Ini merupakan suatu upaya yang diatur melalui perundang-undangan untuk melindungi martabat dan kesucian perkawinan, dan lebih khusus lagi perempuan dalam kehidupan rumah tangga melalui pencatatan perkawinan yang dibuktikan dengan akta nikah yang masing-masing suami istri mendapat salinannya.

Jika terjadi perselisihan atau percekcokan di antara suami istri, atau salah satu tidak bertanggung jawab, maka yang lain dapat melakukan upaya hukum guna mempertahankan atau memperoleh hak-hak masing-masing, karena dengan akta tersebut suami istri memiliki bukti otentik at as perbuatan hukum yang telah ada. Akta nikah atau bukti catatan perkawinan juga berguna untuk membuktikan keabsahan anak dari hasil perkawinan itu. Upaya hukum ke Pengadilan tentu tidak dapat dilakukan, apabila perkawinan tidak dibuktikan dengan akta tersebut.

\footnotetext{
${ }^{6}$ Ahmad Rofiq, Hukum Islam di Indonesia (Jakarta: PT Raja Grafindo Persada, 1995), h. 56.

${ }^{7}$ Republik Indonesia, Undang-Undang Nomor 1 Tahun 1974 tentang Perkawinan, Pasal 2 Ayat (2).
} 
Kompilasi Hukum Islam (KHI) pasal 7 ayat (1) menegaskan "perkawinan hanya dapat dibuktikan dengan akta nikah yang dibuat oleh pegawai pencatat nikah."8 Maksud dari pencatatan perkawinan adalah sesuai dengan pasal 2 ayat 2 UUP bahwa perkawinan itu harus dicatatkan kepada pegawai pencatat nikah di KUA bagi yang beragama Islam, sementara yang beragama non Islam dapat dilakukan di Kantor Catatan Sipil menurut ketentuan undang-undang yang berlaku.

Meskipun dalam UUP sudah diberlakukan dengan jelas dan tegas bahwa perkawinan itu harus dicatat, namun di dalam prakteknya masalah pencatatan perkawinan ini menjadi suatu problem di masyarakat, khususnya terhadap perkawinan di bawah umur. Banyak masalah yang sering terjadi dalam proses pencatatan nikah pada perkawinan di bawah umur yang terjadi akibat dari kelalaian dari kedua belah pihak, baik yang dilakukan oleh pelaku perkawinan itu sendiri bersama dengan orang tuanya yang bertanggung jawab terhadap anaknya yang menikah, juga dilakukan oleh petugas pencatat nikah yang tidak tertib administrasi.

Realita yang terjadi di Kabupaten Gorontalo dalam proses pencatatan perkawinan di bawah umur bahwa pencatatan nikah yang dilakukan setelah perkawinan, artinya bahwa perkawinan didahulukan kemudian pencatatan dilakukan belakangan, hal ini banyak dilakukan dengan alasan karena pihak tidak ingin melakukan dispensasi nikah di pengadilan hingga menunggu umur salah satu atau keduanya cukup dulu, dan alasan lain karena perkawinan sudah sangat mendesak untuk dilakukan.

Selain itu juga pencatatan nikah dilakukan setelah lahirnya anak pertama. Hal ini banyak dilakukan karena kelalaian pihak itu sendiri yang tidak memahami betapa pentingnya melakukan pencatatan perkawinan, ketika dibutuhkan akta perkawinan barulah melakukan proses pencatatan, kejadian seperti ini biasanya terjadi pada perkawinan yang dilakukaan secara illegal, sehingga akibatnya adalah sang anak tidak masuk dalam perkawinan, sebab orang tuanya harus kembali diakad dan pencatatannya dilakukan pada tanggal yang sama.

\footnotetext{
${ }^{8}$ Republik Indonesia, Instruksi Presiden Nomor 1 Tahun 1991 tentang Penyebarluasan Kompilasi Hukum Islam, Pasal 7 Ayat (1)
} 


\section{Kelalaian Pencatatan Nikah Pada Perkawinan di Bawah Umur}

di Kabupaten Gorontalo

Kejadian yang lainnya perkawinan dilakukan sebelum keluarnya izin dispensasi nikah dari Pengadilan Agama, hal ini dilakukan karena perkawinan telah direncanakan terlebih dahulu dengan hari pelaksanaan yang sudah disepakati, namun setelah melakukan pendaftaran nikah di KUA terjadi penolakan pencatatan karena harus dispensasi nikah dulu, dalam kejadian seperti ini banyak yang justru berani melakukan perkawinan dan berpikir bahwa pencatatan nikah boleh dilakukan belakangan.

Ini juga terjadi pencatatan nikah dilakukan dengan metode tanggal yang mundur, meskipun kejadian seperti ini sudah jarang terjadi lagi tetapi ini banyak kali terjadi pada proses pencatatan nikah anak di bawah umur. Hal ini menjadi sebuah kelalaian petugas pencatat nikah dengan alasan yang cukup mendesak. Selain itu pencatatan nikah dilakukan dengan metode menambah umur calon pengantin, ini juga kerap kali terjadi dalam proses pencatatan nikah perkawinan di bawah umur yang terjadi di KUA, biasanya kelalaian seperti ini dilakukan oleh Pembantu PPN yang ada di desa, karena Penghulu dan Pembantu PPN yang bersentuhan langsung dengan masyarakatnya demi untuk menghindari adanya proses dispensasi nikah yang akan memperlambat pelaksanaan perkawinan.

Beberapa permasalahan tersebut yang banyak sekali terjadi pada masyarakat Kabupaten Gorontalo terhadap proses pencatatan perkawinan di bawah umur. Pemahaman masyarakat terhadap aturan perundang-undangan yang sangat rendah bisa menjadi penyebab banyaknya kelalaian dalam pencatatan perkawinan di bawah umur. Padahal banyak yang tidak menyadari dampak yang nantinya akan ditimbulkan ketika hal ini, seperti anak yang lahir di luar perkawinan karena pencatatannya dilakukan setelah anak lahir, dan juga dampak buruk terhadap institusi pencatatan nikah yaitu KUA yang bertanggung jawab melakukan pencatatan nikah, yang pasti orang awam justru akan menggampangkan proses pencatatan nikah, sebab tidak ada ketegasan dalam aturan yang ditegakkan.

Seandainya saja aturan pencatatan nikah di Indonesia yang sudah dikemas dalam bentuk undang-undang ini memberikan ganjaran bagi pelaku perkawinan yang tidak tertib administrasi, maka bisa jadi akan lebih baik lagi proses pencatatan nikah yang sudah ada. Berbeda dengan apa yang terjadi di beberapa negara Islam seperti Iran, 
Yordania dan Palestina. Uqlah menjelaskan misalnya di Yordania yang memberikan ganjaran berupa hukuman fisik atau penjara bagi pelaku perkawinan yang melanggarnya harus membayar denda 100 dinar. ${ }^{9}$ Al-Syarthawi menjelaskan bahwa apabila pernikahan terlaksana tanpa rekomendasi pernikahan dari pengadilan resmi, maka yang menikahkan kedua mempelai dan saksi dihukum sesuai dengan undangundang pidana kerajaan Yordania dengan hukuman membayar denda setiap pelakunya 100 dinar. Selain itu bagi petugas pencatat nikah yang lalai melaksanakan tugasnya untuk mencatat dalam catatan resmi pengadilan, dijatuhi hukuman denda dan pemecatan dari kepegawaian. ${ }^{10}$ Meskipun pada dasarnya perkawinan tetap sah jika tidak dicatatkan yang penting sesuai dengan ketentuan hukum Islam, namun pencatatan perkawinan di Indonesia sangatlah penting untuk dilakukan.

Proses pencatatan nikah saat ini telah menjadi masalah krusial didalam masyarakat di Indonesia termasuk apa yang terjadi di Kabupaten Gorontalo, tidak sedikit perkawinan dib awah umur yang telah terjadi justru tidak dicatatkan kepada pihak berwenang yang sampai saat ini tidak memiliki buku nikah, sehingga banyak menimbulkan persoalan dalam masyarakat. Berdasarkan data awal yang ditemukan melalui observasi awal untuk tahun 2018 ada 10 perkawinan di bawah umur khusus yang tercatat di KUA Kecamatan Telaga Biru, 3 di antaranya perkawinan dilakukan pada tahun 2017 tetapi dicatatkan pada tahun 2018, sehingga permasalahan yang ada dalam proses pencatatan nikah ini, maka penting untuk melihat mengapa terjadi kelalaian pada proses pencatatan nikah yang terjadi pada perkawinan di bawah umur di Kabupaten Gorontalo.

\section{B. Pencatatan Perkawinan Anak di Bawah Umur}

Syariat Islam tidak mengatur secara konkret pencatatan perkawinan. Ini berbeda dengan muamalat (mudayanah) yang dilakukan tidak secara tunai untuk waktu tertentu, diperintahkan untuk mencatatnya. Tuntutan perkembangan, dengan berbagai pertimbangan kemaslahatan, hukum perdata Islam di Indonesia perlu mengaturnya

\footnotetext{
${ }^{9}$ Muhammad Uqlah, Nidham al-Usrah fi al-Islam, Juz I (Amman: Maktabah al-Risalah alHaditsah, 1989), 395.

${ }^{10}$ Muhammad Ali al-Syarthawi, Syarh Qanun al-Ahwal al-Syakhshiyah (Amman: Dar al-Fiqr, 1997), 139-140.
} 


\section{Kelalaian Pencatatan Nikah Pada Perkawinan di Bawah Umur} di Kabupaten Gorontalo

guna kepentingan kepastian hukum di dalam masyarakat. ${ }^{11}$ Terkait muamalah (mudayanah), yaitu QS al-Baqarah/2: 282 yang menjadi dasar hukum hutang piutang: "Wahai orang-orang yang beriman! Apabila kamu melakukan utang piutang untuk waktu yang ditentukan, hendaklah kamu menuliskannya. Dan hendaklah seorang penulis di antara kamu menuliskannya dengan benar...."

Ayat tersebut menunjukkan bahwa adanya anjuran, bahkan sebagian ulama menyatakan bahwa anjuran ini bersifat kewajiban untuk mencatat utang piutang dan mendatangkan saksi dihadapan pihak ketiga yang dipercaya. Selain itu, ayat ini juga menekankan perlunya menulis utang walaupun hanya sedikit, disertai dengan jumlah dan ketetapan waktunya, bertujuan untuk menghindarkan terjadinya sengketa dikemudian hari. ${ }^{13}$ Ayat ini dapat ditarik istinbath dengan qias (aulawi) yaitu sesuatu yang tidak ditegaskan lebih ulama hukumnya daripada yang ditegaskan. Dengan qiyas (aulawi) bahwa jika perjanjian yang berhubungan dengan harta saja dianjurkan untuk dicatatkan d iatas hitam dan putih, bagaimana dengan perkawinan, sebagai ikatan lahir bathin antara laki-laki dan perempuan yang disebut dalam al-Quran sebagai mitsaqon ghalidza dengan tujuan membina keluarga sakinah, mawaddah wa rahmah. ${ }^{14}$

Pencatatan pernikahan adalah pendataan administrasi perkawinan yang ditandatangani oleh Pegawai Pencatat Nikah (PPN) dengan tujuan untuk menciptakan ketertiban perkawinan dalam masyarakat, baik pelaksanaan perkawinan berdasarkan hukum Islam maupun perkawinan yang dilaksanakan oleh masyarakat tidak berdasarkan hukum Islam. ${ }^{15}$ Kutipan akta nikah itu sebagai bukti otentik yang dilakukan oleh Pegawai Pencatat Nikah, Talak, dan Rujuk. Juga oleh pegawai pencatat pernikahan pada kantor catatan sipil sebagai dimaksud dalam perundang-undangan yang berlaku mengenai pencatatan pernikahan. ${ }^{16}$

\footnotetext{
${ }^{11}$ Ahmad Rofiq, Hukum Perdata Islam di Indonesia (Jakarta: PT. Raja Grafindo Persada, 2013), 91.

${ }^{12}$ Kementerian Agama RI, Ummul Mukminin: Al-Qur'an dan Terjemah untuk Wanita (Jakarta: Penerbit Wali, 2010), 48.

${ }^{13}$ M. Quraish Shihab, Tafsir al-Misbah (Jakarta : Lentera Hati, 2004), 602.

${ }^{14} \mathrm{https}$ ://asy79aulia.wordpress.com/2012/12/28/pencatatanperkawinan-sebuah-tinjauan-yuridismenurut-hukum-islam-dan-undang-undang-nomor-1-tahun- 1974/, diakses pada 15 April 2019.

${ }^{15}$ Zainudin Ali, Hukum Perdata Islam di Indonesia (Jakarta: Sinar Grafika, 2006), 26.

${ }^{16}$ Arso Sastroatmodjo dan Awasit Aulawi, Hukum Perkawinan Indonesia (Jakarta: Bulan Bintang, 1978), 56.
} 
Urgensi pencatatan untuk legalitas pernikahan ditunjukkan dengan adanya akta nikah. Akta nikah bisa digunakan untuk mengurus akte kelahiran anak, keperluan terkait status perkawinan, dan sebagainya. Pencatatan pernikahan pada prinsipnya merupakan hak dasar dalam sebuah keluarga. Selain itu pencatatan juga merupakan bentuk perlindungan terhadap istri maupun anak dalam memperoleh hak-hak dalam keluarga, seperti nafkah, hadhanah, status nasab, waris, dan lain sebagainya. Tanpa adanya akta nikah, hak-hak seorang isteri atau anak dalam memperoleh hak-haknya dalam keluarga dapat saja diragukan. Olehnya itu dasar hukum pencatatan pernikahan di Indonesia, antara lain:

a. Undang-Undang Nomor 22 Tahun 1946 tentang Pencatatan Nikah, Talak dan Rujuk

Nikah yang dilakukan menurut agama Islam, selanjutnya disebut nikah, diawasi oleh pegawai pencatat nikah yang diangkat oleh Menteri Agama atau pegawai yang ditunjuk olehnya. Talak dan rujuk yang dilakukan menurut agama Islam, selanjutnya disebut talak dan rujuk, diberitahukan kepada pegawai pencatat nikah. ${ }^{17}$

b. Undang-Undang Nomor 1 Tahun 1974 tentang Perkawinan

Tiap-tiap perkawinan dicatat menurut peraturan perundang-undangan yang berlaku. $^{18}$

c. Kompilasi Hukum Islam (KHI)

(1) Agar terjamin ketertiban perkawinan bagi masyarakat Islam setiap perkawinan harus dicatat.

(2) Pencatatan perkawinan tersebut pada ayat (1), dilakukan oleh Pegawai Pencatat Nikah sebagaimana yang diatur dalam Undang-Undang Nomor 22 Tahun 1946 jo. Undang-Undang Nomor 32 Tahun $1954 .{ }^{19}$

d. Peraturan Pemerintah Nomor 9 Tahun 1975 tentang Pelaksanaan Undang-Undang Nomor 1 Tahun 1974 tentang Perkawinan

\footnotetext{
${ }^{17}$ Republik Indonesia, Undang-Undang Nomor 22 Tahun 1946 tentang Pencatatan Nikah, Talak dan Rujuk, Pasal 1 Ayat (1). Lihat juga Republik Indonesia, Undang-Undang Nomor 32 Tahun 1954 tentang Penetapan Berlakunya Undang-Undang Republik Indonesia Tanggal 21 Nopember 1946 No. 22 Tahun 1946 tentang Pencatatan Nikah, Talak dan Rujuk di Seluruh Daerah Luar Jawa dan Madura. 2.

${ }^{18}$ Republik Indonesia, Undang-Undang Nomor 1 Tahun 1974 tentang Perkawinan, Pasal 2 Ayat

${ }^{19}$ Republik Indonesia, Instruksi Presiden Nomor 1 Tahun 1991 tentang Penyebarluasan Kompilasi Hukum Islam, Pasal 5 ayat (1).
} 
Kelalaian Pencatatan Nikah Pada Perkawinan di Bawah Umur

di Kabupaten Gorontalo

Pencatatan Perkawinan dari mereka yang melangsungkan perkawinannya menurut Agama Islam, dilakukan oleh Pegawai Pencatat sebagaimana dimaksud dalam Undang-Undang Nomor 32 tahun 1954 tentang Pencatat Nikah, Talak, dan Rujuk ${ }^{20}$

e. Undang-Undang No. 23 Tahun 2006 tentang Administrasi Kependudukan

Peristiwa Penting adalah kejadian yang dialami oleh seseorang meliputi kelahiran, kematian, lahir mati, perkawinan, perceraian, pengakuan anak, pengesahan anak, pengangkatan anak, perubahan nama dan perubahan status kewarganegaraan. ${ }^{21}$

Setiap Penduduk wajib melaporkan Peristiwa Kependudukan dan Peristiwa Penting yang dialaminya kepada Instansi Pelaksana dengan memenuhi persyaratan yang diperlukan dalam Pendaftaran Penduduk dan Pencatatan Sipil. $^{22}$

Beberapa aturan inilah yang menjadi dasar pelaksanaan pencatatan perkawinan di Indonesia. Pada prinsipnya pencatatan nikah bertujuan untuk mewujudkan ketertiban pernikahan dalam masyarakat. Ini merupakan suatu upaya yang diatur melalui perundang-undangan untuk melindungi martabat dan kesucian pernikahan dan khususnya bagi perempuan dalam kehidupan rumah tangga. Melaui pencatatan nikah yang dibuktikan oleh akta apabila terjadi perselisihan antara suami isteri, maka salah satunya atau keduanya dapat melakukan upaya hukum guna mempertahankan atau memperoleh hak masing-masing. ${ }^{23}$

\section{Bentuk Kelalaian Pencatatan Nikah Pada Perkawinan di Bawah Umur di Kabupaten Gorontalo}

Pencatatan perkawinan adalah suatu administrasi negara dalam rangka menciptakan ketertiban dan kesejahteraan warga negaranya. Bentuk pencatatan yang dimaksud adalah memasukkan peristiwa pernikahan itu dalam buku akta nikah kepada masing-masing suami isteri. Kemudian kutipan akta nikah itu sebagai bukti otentik

\footnotetext{
${ }^{20}$ Republik Indonesia, Peraturan Pemerintah Nomor 9 Tahun 1975 tentang Pelaksanaan Undang-Undang Nomor 1 Tahun 1974 tentang Perkawinan, Bab II Pasal 2 ayat 1

${ }^{21}$ Republik Indonesia, Undang-Undang Nomor 23 Tahun 2006 tentang Administrasi Kependudukan, Pasal 1 Ayat 17.

${ }^{22}$ Ibid., Pasal 3.

${ }^{23}$ Ahmad Rofiq, Hukum Islam di Indonesia , 108.
} 
yang dilakukan oleh Pegawai Pencatat Nikah, Talak, dan Rujuk. Juga oleh pegawai pencatat pernikahan pada Kantor Catatan Sipil sebagai dimaksud dalam perundangundangan yang berlaku mengenai pencatatan pernikahan.

Perkawinan yang tidak dicatatkan sama saja dengan membiarkan adanya hidup bersama di luar perkawinan, juga sangat merugikan para pihak yang terlibat, terutama perempuan, terlebih lagi kalau sudah ada anak-anak yang dilahirkan. Anak yang dilahirkan dari orang tua yang hidup bersama tanpa dicatatkan perkawinannya adalah anak luar kawin yang hanya mempunyai hubungan hukum dengan ibunya, dalam arti tidak mempunyai hubungan hukum dengan ayahnya.

Realitas perkawinan di bawah umur yang banyak terjadi di Kabupaten Gorontalo penting menjadi perhatian bersama dalam rangka melakukan pencegahan dini baik dari pemerintah terkait maupun dari masyarakat yang mempraktikannya, agar ketertiban pelaksanaan perkawinan di masyarakat semakin baik dan anak-anak yang melakukan perkawinan pun terlindungi kepentingannya. Data yang diperoleh terkait perkawinan di bawah ini di Kabupaten Gorontalo, yaitu:

Tabel 1.

Data Perkawinan Kabupaten Gorontalo Tahun 2016-2018

\begin{tabular}{||c|l|c|c|c|c|c|c||}
\hline \multirow{2}{*}{ No } & \multirow{2}{*}{ Kecamatan } & \multicolumn{3}{|c|}{ Jumlah Perkawinan } & \multicolumn{3}{c|}{ Perkawinan Di Bawah Umur } \\
\cline { 3 - 8 } & & $\mathbf{2 0 1 6}$ & $\mathbf{2 0 1 7}$ & $\mathbf{2 0 1 8}$ & $\mathbf{2 0 1 6}$ & $\mathbf{2 0 1 7}$ & $\mathbf{2 0 1 8}$ \\
\hline \hline $\mathbf{1}$ & Telaga & 258 & 199 & 200 & 0 & 2 & 3 \\
\hline $\mathbf{2}$ & Telaga Biru & 202 & 257 & 246 & 6 & 5 & 5 \\
\hline $\mathbf{3}$ & Talaga Jaya & - & 71 & 116 & 0 & 0 & 0 \\
\hline $\mathbf{4}$ & Tilango & 117 & 127 & 128 & 0 & 0 & 0 \\
\hline $\mathbf{5}$ & Batudaa Pantai & 72 & 127 & 128 & 0 & 0 & 0 \\
\hline $\mathbf{6}$ & Batudaa & 133 & 151 & 153 & 1 & 3 & 1 \\
\hline $\mathbf{7}$ & Biluhu & 54 & 63 & 72 & 0 & 0 & 0 \\
\hline $\mathbf{8}$ & Tabongo & 124 & 159 & 182 & 0 & 0 & 0 \\
\hline $\mathbf{9}$ & Bongomeme & 284 & 324 & 355 & 33 & 29 & 20 \\
\hline $\mathbf{1 0}$ & Tibawa & 328 & 396 & 372 & 90 & 102 & 77 \\
\hline $\mathbf{1 1}$ & Pulubala & 414 & 522 & 466 & 27 & 33 & 21 \\
\hline $\mathbf{1 2}$ & Boliyohuto & 223 & 234 & 264 & 8 & 9 & 6 \\
\hline $\mathbf{1 3}$ & Tolangohula & 188 & 195 & 195 & 2 & 2 & 0 \\
\hline $\mathbf{1 4}$ & Mootilango & 162 & 187 & 189 & 26 & 19 & 18 \\
\hline $\mathbf{1 5}$ & Asparaga & 97 & 102 & 99 & 0 & 0 & 0 \\
\hline $\mathbf{1 6}$ & Limboto Barat & 434 & 398 & 476 & 21 & 11 & 10 \\
\hline $\mathbf{1 7}$ & Limboto & 426 & 466 & 411 & 69 & 18 & 21 \\
\hline & Jumlah & $\mathbf{3 . 5 1 6}$ & $\mathbf{3 . 9 5 0}$ & $\mathbf{4 0 3 0}$ & $\mathbf{2 8 3}$ & $\mathbf{2 3 3}$ & $\mathbf{1 8 2}$ \\
\hline
\end{tabular}




\section{Kelalaian Pencatatan Nikah Pada Perkawinan di Bawah Umur}

di Kabupaten Gorontalo

Tabel 1 menunjukkan bahwa perkawinan di bawah umur tahun 2016-2018 di Kabupaten Gorontalo masih cukup tinggi, namun mengalami penurunan dari tahun 2017 dan 2018. Tentunya dari data ini akan diperoleh data pencatatan perkawinan yang sering dilalaikan oleh berbagai pihak terutama oleh para pelaku perkawinan itu sendiri. Berdasarkan hasil penelitian yang telah dilakukan terhadap kelalaian pencatatan perkawinan terdapat tiga bentuk kelalaian dalam pencatatan perkawinan di Kabupaten Gorontalo.

\section{Kelalaian Orang Tua}

Terhadap pencatatan perkawinan yang telah jelas aturannya sudah ada sejak lama namun masih banyak permasalahan seperti ini ditemukan di masyarakat. Hal ini disebabkan oleh kelalaian dari pihak terkait didalamnya. Orang tua merupakan salah satu pihak yang dianggap paling bertangggung jawab dalam persoalan perkawinan anak di bawah umur, sebab tanggung jawab orang tua terhadap anak tidak hanya sebatas melahirkan, merawat, membesarkan dan menyekolahkan saja, tetapi lebih dari itu ada hal yang paling penting dapat dilakukan orang tua terhadap anak-anaknya, yaitu dengan tidak memutus masa depan anak-anak hanya karena perkawinan yang belum layak untuk dilakukan. Di Kabupaten Gorontalo menunjukkan kelalaian pencatatan nikah sering dilakukan pada proses perkawinan anak di bawah umur, kelalaian ini paling banyak dilakukan oleh orang tua pelaku perkawinan anak di bawah umur.

Adapun bentuk kelalaian pencatatan perkawinan di bawah umur yang dilakukan oleh orang tua di Kabupaten Gorontalo antara lain:

a. Tidak Melaporkan Perkawinan ke Pihak Pencatat Nikah

Perkawinan di bawah umur yang banyak tidak dicatatkan perkawinannya diakibatkan oleh orang tua itu sendiri yang lebih mementingkan pelaksanaan pesta perkawinannya dari pada pencatatannya, sehingga orang tua tidak melaporkan perkawinannya kepada petugas pencatatan nikah, baik yang di Desa maupun yang di KUA. Melihat banyaknya kasus perkawinan seperti ini yang dilakukan secara terbuka di masyarakat tetapi tidak dicatatkan sebenarnya penting juga untuk menjadi perhatian dari unsur pemerintah, tidak adanya sanksi dari kasus seperti ini mengakibatkan 
semakin meluas perkawinan tidak tercatat dilakukan di masyarakat. Data di lapangan menunjukkan ada 6 pasangan yang tidak melaporkan ke pihak KUA atau PPN.

\section{b. Ketidaktahuan Prosedur Pencatatan Perkawinan}

Prosesdur pencatatan perkawinan sudah sejak lama berlaku di Indonesia, jadi mustahil jika ada orang tua yang tidak memahami prosedur pencatatan perkawinan. Tidak tercatatnya perkawinan di bawah umur akibat dari ketidakpahaman prosedur pencatatan nikah lebih banyak dipengaruhi oleh kurangnya komunikasi di masyarakat, dan biasanya orang tua telah menyerahkan urusan seperti ini kepada orang lain yang dianggap lebih memahami, tetapi sampai perkawinan selesai ternyata orang tua baru menyadari perkawinan yang dilakukan anaknya tidak tercatat. Kejadian ini terjadi pada 182 pasangan yang menikah di Kabupaten Gorontalo.

c. Perkawinan Sudah Mendesak

Salah satu bentuk kelalaian orang tua dalam pencatatan perkawinan di bawah umur adalah karena perkawinan yang dilakukan telah mendesak. Penting untuk dipahami bahwa perkawinan di bawah umur bukanlah perkawinan normal yang telah direncanakan secara matang sebelumnya, biasanya perkawinan dibawah umur merupakan perkawinan yang sangat mendesak untuk dilaksanakan sehingga dalam tahapan persiapannya dilakukan secara singkat dan pencatatan perkawinan pun terabaikan karena desakan untuk segera dinikahkan. Data perkawinan yang sudah mendesak sebanyak 182 pernikahan.

\section{d. Tidak Adanya Persetujuan Orang Tua}

Orang tua merupakan tumpuan hidup anak-anaknya yang memiliki beban tanggungjawab yang begitu besar untuk anak-anaknya, sesuatu hal yang wajar dilakukan orang tua jika disaat anaknya menikah ada ketidak setujuan orang tua dalam perkawinan tersebut dengan alasan yang logis, misalnya masih dalam usia sekolah yang dihawatirkan orang tua tentang masa depannya yang tidak pasti, selain itu alasan karena anak telah melanggar aturan yang diterapkan dalam rumah tangga, sehingga tidak jarang banyak terjadi di Kabupaten Gorontalo. Hal demikian yang mengakibatkan kelalaian orang tua dalam mencatatkan perkawinan anaknya karena dalam perkawinan yang dilakukan orang tua tidak memberikan restu untuk menikah. 


\section{Kelalaian Pencatatan Nikah Pada Perkawinan di Bawah Umur}

di Kabupaten Gorontalo

Hasil penelitan dari 182 pernikahan yang tidak mendapatkan restu orang tua sebanyak 50 pernikahan.

Membicarakan hal-hal yang menjadi kewajiban seorang ayah ketika anaknya menyatakan akan menikah dengan pasangan hidupnya. Ketika pasangan datang kepada orang tua untuk meminta restu menikahi anaknya, maka peran ayah sebagai orang tua menjadi penting apakah merestui atau tidak. Peran seorang ayah sebagai imam di keluarga yang juga akan berperan sebagai wali dalam perkawinan tidak dapat diabaikan anak ketika akan menikah, orang tua harus terlibat secara penuh dalam perkawinan Kewajibannya sebagai orang tua akan diserahkan kepada sepenuhnya kepada suami, maka wajarlah kehawatiran seorang ayah pasti ada disaat akan menikahkan anak-anaknya yang masih di bawah umur.

Kelalaian orang tua dalam perkawinan anak di bawah umur ini dapat dilihat bahwa tidak semuanya terjadi karena ada unsur kesengajaan tetapi juga karena ada unsur ketidaksengajaan yang terjadi saat itu. Pencatatan perkawinan menjadi unsur yang sangat penting bagi keabsahan perkawinan. Hal ini dimaksudkan untuk melindungi warga negara dalam membina keluarga, selain itu perkawinan yang dicatatkan akan memberikan kepastian dan perlindungan serta kekuatan hukum bagi suami, isteri dan anak-anak, juga memberikan jaminan dan perlindungan terhadap hakhak tertentu yang timbul karena perkawinan antara lain hak untuk mewaris dan sebagainya.

Penting untuk dipahami bahwa salah satu asas perkawinan adalah legalitas, dalam undang-undang perkawinan yang tidak kalah penting terutama di era hukum tertulis dengan kodifikasi hukum sebagai ciri utamanya ialah asas legalitas, yang pada intinya mengajarkan bahwa setiap perkawinan wajib dicatat oleh petugas (pejabat) yang berwenang. Asas legalitas dalam perkawinan seyogyanya tidak dipahami dalam konteks administratif semata, tetapi idealnya juga memiliki nilai hukum normatif yang bersifat mengikat dalam pengertian pencatatan perkawinan akan turut menentukan sah tidaknya sebuah akad nikah yang dilangsungkan sepasang pengantin (laki-laki dan perempuan). Oleh sebab itu jika orang tua lalai dalam mencatatkan perkawinan anak- 
anaknya maka akibat hukum yang ditimbulkan pun akan semakin besar di masyarakat terutama pada pasangan pengantin yang akan menikah.

\section{Kelalaian Anak}

UUP pada prinsipnya tidak mengenal adanya perkawinan di bawah umur ataupun pernikahan dewasa, namun UUP hanya memberi batasan minimal usia ideal bagi warga negara untuk menikah, yaitu membolehkan laki-laki berumur di bawah 19 tahun dan perempuan di bawah 16 tahun untuk menikah, ${ }^{24}$ selama mendapatkan dispensasi nikah dari Pengadilan Agama. Dispensasi nikah sebagai bentuk perlindungan terhadap anak di bawah umur yang akan menikah untuk mendapatkan legalitasnya, namun ternyata sejauh ini kelonggaran dispensasi nikah dan kebolehan menikah di bawah umur ini dimanfaatkan oleh para muda-mudi untuk melakukan halhal yang seharusnya terlarang untuk dilakukan dengan dalih akan menikahi pasangannya.

Proses dispensasi nikah yang panjang persoalannya di Pengadilan membuat banyak masyarakat yang akan menikah tidak melalukan proses ini meskipun telah diketahui informasinya, sehingga hal ini menyebabkan banyaknya perkawinan yang tidak dicatatkan di Kabupaten Gorontalo. Kelalaian anak dalam persoalan pencatatan nikah pada perkawinan di bawah umur berdasarkan hasil penelitian ditemukan salah satu persoalannya adalah kondisi anak yang telah hamil di luar nikah yang segera untuk dinikahkan dengan jumlah perkawinan sebanyak 182.

Kelalaian menjaga kehormatan dan menjaga diri yang berakibat pada anak di bawah umur hamil sebelum adanya ikatan perkawinan menunjukan adanya aturan yang terlalu memberikan kelonggaran terhadap persoalan perkawinan, padahal jika ada sanksi yang akan menjerat pelaku perkawinan seperti ini maka akan memungkinkan untuk menurunkan angka perkawinan di bawah umur yang bermasalah dan meminimalisir perkawinan yang tidak tercatat.

\footnotetext{
${ }^{24}$ Republik Indonesia, Undang-Undang Nomor 1 Tahun 1974 tentang Perkawinan, Pasal 7 Ayat (1); namun terkait batas umur pernikahan telah diubah menjadi 19 tahun bagi laki-laki dan wanita. Lihat Republik Indonesia, Undang-Undang Nomor 16 Tahun 2019 tentang Perubahan Atas Undang-Undang Nomor 1 Tahun 1974 tentang Perkawinan, Pasal 7.
} 


\section{Kelalaian Pencatatan Nikah Pada Perkawinan di Bawah Umur} di Kabupaten Gorontalo

Aturan tentang persoalan perkawinan di bawah umur sangat penting untuk dilakukan penyesuaian kondisi sekarang yang semakin parah terhadap persoalan perkawinan yang banyak tidak dicatatkan khususnya perkawinan dibawah umur yang terjadi akibat dari ketidakpahaman prosedur pencatatan perkawinan dan kelalaian dari anak itu sendiri. Legalitas pencatatan perkawinan penting untuk dilakukan di masa sekarang, karena perkawinan yang tidak tercatat secara hukum tidak akan diakui keberadaannya di Indonesia, meskipun dilakukan secara sah berdasarkan ketentuan yang berlaku dalam hukum Islam.

\section{Kelalaian Petugas Pencatat Nikah}

Menurut Peraturan Menteri Agama Nomor 11 Tahun 2007 disebutkan ada beberapa pihak yang diberi amanat untuk melakukan pencatatan nikah di KUA, misalnya ada Pegawai Pencatat Nikah (PPN), Penghulu dan Pembantu Pegawai Pencatat Nikah (PPN/P3N). Penjelasan dalam aturan tersebut, yaitu yang dimaksud "Pegawai Pencatat Nikah adalah pejabat yang melakukan pemeriksaan persyaratan, pengawasan, dan pencatatan peristiwa nikah/rujuk, pendaftaran cerai talak, cerai gugat, dan melakukan bimbingan perkawinan, dalam hal ini dijabat oleh Kepala KUA." ${ }^{25}$ Kemudian yang dimaksud dengan "Penghulu adalah pejabat fungsional Pegawai Negeri Sipil yang diberi tugas dan tanggung jawab, dan wewenang untuk melakukan pengawasan nikah dan rujuk menurut agama Islam dan kegiatan kepenghuluan." Sefdangkan Pembantu PPN/P3N merupakan anggota masyarakat tertentu yang diangkat oleh Kepala Kantor Kementerian Agama Kabupaten/Kota untuk membantu tugas-tugas PPN di desa tertentu.

Berdasarkan hal tersebut jelaslah siapa saja yang memiliki tanggung jawab dan berwenang untuk melakukan pencatatan perkawinan di wilayah Kecamatan dan Desa. Hasil penelitian yang telah dilakukan memang kekeliruan dan kelalaian dalam pencatatan nikah lebih banyak dilakukan oleh masyarakat yang akan mencatatkan perkawinannya di KUA, khususnya orang tua dan anak yang akan menikah, juga di tingkatan PPN dan Pembantu PPN sering terjadi kelalaian dalam pencatatan nikah.

\footnotetext{
${ }^{25}$ Republik Indonesia, Peraturan Menteri Agama Nomor 11 Tahun 2007 tentang Pencatatan Nikah, Pasal 2 ayat (1) dan (2).

${ }^{26}$ Ibid., Pasal 1 Angka 5
} 
Kekeliruan yang biasanya terjadi adalah berkas pencatatan nikah tidak sampai di meja Kepala KUA atau hanya sampai pada Pembantu PPN, hal ini terjadi pada perkawinan yang berada di daerah terpencil yang sulit menjangkau lokasi Kantor KUA Kecamatan. Selain itu kelalaian pula dapat terjadi pada tingkatan PPN yang memiliki tanggungjawab mencatatkan perkawinan seperti tidak keluarnya buku akta nikah meskipun sudah didaftarkan sesuai dengan persyaratan yang ada.

Salah satu kelalaian yang pernah juga dilakukan dalam pencatatan perkawinan pada tinngkatan PPN di Kabupaten Gorontalo, seperti yang terjadi di KUA Kecamatan Telaga Biru yang setelah dilakukan akad nikah baru diketahui oleh petugas pencatat nikah bahwa anak tersebut belum cukup umur untuk menikah. Akhirnya perkawinan tetap dilanjutkan namun pencatatan di tunda sampai umur pasangan tersebut mencukupi dan kejadian ini hanya terjadi pada 1 lokasi KUA.

Oleh sebab itu pencatatan perkawinan harus dilakukan dengan teliti dan cermat, terkadang ada perkawinan yang mengakali perkawinannya telah cukup umur tetapi ternyata belum cukup, ada juga yang merubah tahun kelahirannya agar dianggap cukup umur dan dapat dicatatkan perkawinannya. Kelalaian kecil seperti yang dilakukan oleh petugas pencatat nikah di KUA dapat memberikan dampak pada perkawinan, khususnya pada perkawinan anak di bawah umur yang tidak akan mendapatkan pengakuan secara sah dalam pernikahannya selama tidak memiliki bukti otentik perkawinan terjadi.

\section{Akibat Hukum Kelalaian Pencatatan Nikah Pada Perkawinan di Bawah Umur di Kabupaten Gorontalo}

Berdasarkan hasil penelitian yang telah dilakukan di Kabupaten Gorontalo terhadap kelalaian pencatatan perkawinan, maka ditemukan akibat hukum dari kelalaian pencatatan perkawinan.

1. Legalitas Anak Hasil Perkawinan

Perkawinan yang tidak dicatatkan sebagaimana banyak dilakukan oleh perkawinan di bawah umur di Kabupaten Gorontalo akibat dari kelalaian yang dilakukan oleh pihak-pihak terkait memberikan akibat hukum pada legalitas anak hasil 


\section{Kelalaian Pencatatan Nikah Pada Perkawinan di Bawah Umur}

di Kabupaten Gorontalo

perkawinan. Bentuk pencatatan perkawinan yang dilakukan pelaku perkawinan dengan mencatatkan perkawinannya setelah terjadi akad nikah bahkan pencatatannya ditunda sampai menunggu cukup umur menyebabkan anak hasil perkawinan, terhitung sebagai anak di luar nikah karena adanya penundaan pencatatan perkawinan.

Hasil penelitian menunjukkan kasus-kasus yang terjadi di Kabupaten Gorontalo adalah anak yang lahir dari hasil perkawinan ini di luar nikah karena kelahirannya terjadi sebelum pencatatan perkawinan, juga terdapat pula anak yang mendapatkan akta kelahiran tetapi statusnya sebagai anak ibu, bahkan ada beberapa yang anaknya berstatus sebagai anak orang tua dan dititipkan pada kartu keluarga orang tua untuk mendapatkan legalitas.

Melihat kondisi dan realitas yang terjadi di masyarakat Kabupaten Gorontalo ini, wajar saja jika di negara Indonesia yang mayoritas penduduknya beragama Islam memberlakukan wajib untuk pencatatan perkawinan, sebab perkawinan merupakan sebuah ikatan suci antara laki-laki dan perempuan dalam mengikatkan janji untuk saling mencintai dalam menjalani hidup berdua, baik menurut agama mupun negara. Antara negara dan agama tidak bisa serta merta dipisahkan begitu saja karena tidak mungkin ada agama yang bisa terlindungi secara baik jika tidak ada negara, begitu pun sebaliknya negara akan kacau jika penduduknya tidak beragama.

Perkawinan yang tidak dicatatkan pada KUA maka perkawinan tersebut dikatakan sebagai perkawinan sirri dan negara tidak dapat bertanggung jawab serta melindungi hak dan kewajiban suami istri apa bila suatu ketika ada yang di rugikan. Oleh karenanya untuk menanggulangi pernikahan yang terlanjur dilaksanakan secara sirri atau terjadi karena kekeliruan dalam pencatatan perkawinan yang dilakukan oleh perkawinan di bawah umur ini, maka dibuatlah undang-undang yang memberikan wewenang pada Pengadilan Agama untuk melaksanakan sidang dispensasi nikah dengan syarat tertentu sesuai dengan aturan yang ada agar mendapat legalitas dan perlindungan negara terhadap perkawinannya.

Pasangan suami istri yang mempunyai anak dari perkawinan yang tidak tercatat dan akan membuatkan akta kelahiran anaknya pada Kantor Catatan Sipil akan mengalami kesulitan, karena salah satu kelengkapan administrasi yang harus dipenuhi 
adalah salinan Kutipan Akta Nikah orang tuanya. Bagi pasangan suami istri yang tidak mempunyai Buku Nikah, maka Kantor Catatan Sipil akan menerbitkan Akta Kelahiran anak tanpa mencantumkan nama bapaknya dalam akta tersebut. Penerbitan Akta Kelahiran semacam itu, sama dengan Akta Kelahiran seorang anak yang tidak mempunyai ayah atau anak di luar nikah, karena hanya dinisbahkan kepada ibunya. Berbeda halnya dengan Akta Kelahiran anak yang perkawinan orang tuanya tercatat, maka nama kedua orang tuanya akan tercantum di dalam akta kelahirannya.

Selain itu, pasangan suami istri yang tidak memiliki Buku Nikah karena perkawinan mereka tidak dicatatkan, yang akan melakukan perceraian di Pengadilan, maka memerlukan proses yang lebih lama dari pada orang yang memiliki Buku Nikah, sebab sebelum pemeriksaan dalil-dalil yang menjadi alasan untuk bercerai, Pengadilan terlebih dahulu akan mengumumkan melalui media massa sebanyak 3 (tiga) kali dalam tenggang waktu 3 (tiga) bulan, minimal satu bulan setelah pengumuman terakhir Pengadilan baru akan memeriksa status perkawinannya, apakah sah atau tidak. Apabila dalam proses pemeriksaan ternyata perkawinan tersebut telah memenuhi syarat dan rukum perkawinan, maka perkawinan mereka akan diisbatkan (KHI Pasal 7 Ayat (3) huruf a). Apabila tidak memenuhi syarat dan rukun perkawinan, maka gugatan atau permohonan mereka untuk bercerai tidak diterima oleh Pengadilan.

Kondisi perkawinan yang tidak tercatat memang akan memberikan dampak buruk terhadap legalitas anak hasil perkawinan dan juga kedudukan seorang perempuan yang telah dinikahi. Sebab keduanya akan tidak jelas statusnya, meskipun secara nyata masyarakat mengetahui perkawinannya terjadi. Keterlambatan pencatatan perkawinan yang dilakukan setelah lahirnya anak hasil perkawinan saja tetap akan tidak diakui keberadaan anak apalagi yang tidak mencatatkan perkawinannya.

\section{Perpisahan atau Perceraian Mudah Terjadi}

Kemampuan seseorang yang hendak menikah terutama bagi laki-laki sebelum berhajat melakukan perkawinan adalah kemampuan fisik, yakni dapat memberikan nafkah baik lahir maupun batin. Oleh karenanya, dalam menjalani kehidupan berumah tangga mutlak diperlukan semangat berkerja keras dan saling pengertian pasangan suami-istri demi terwujudnya kehidupan yang harmonis di dalam membina suatu 


\section{Kelalaian Pencatatan Nikah Pada Perkawinan di Bawah Umur}

di Kabupaten Gorontalo

rumah tangga yang harmonis, rukun, tentram, dan damai. Dengan demikian, setiap perkawinan menghendaki kekekalan dan kebahagiaan dalam rumah tangga. Akan tetapi untuk mencapai kebahagiaan kadangkala terhalang bencana yang menimbulkan kerusakan rumah tangga yaitu perceraian.

Perceraian atau perpisahan dalam sebuah ikatan perkawinan biasanya rentan terjadi juga pada perkawinan dibawah umur yang belum mampu secara fisik dan mental dalam menjalani kehidupan rumah tangga. Kelalaian yang terjadi pada saat proses pencatatan perkawinan yang dilakukan pada perkawinan dibawah umur di Kabupaten Gorontalo dapat pula mengakibatkan beban tanggung jawab suami yang tidak sepenuhnya dilakukan dengan baik dan benar sesuai sehingga suami lebih mudah untuk meninggalkan tanggung jawabnya yang berakibat pada perpisahan.

Berdasarkan hasil penelitian yang telah dilakukan pada perkawinan di bawah umur di Kabupaten Gorontalo yang salah satu akibat hukumnya adalah mudah terjadi perpisahan/perceraian dalam rumah tangga dan dari 182 pernikahan yang terjadi maka 76 perkawinan di bawah umur terjadi perceraian.

\section{Penolakan Dispensasi Nikah}

Perkawinan bagi manusia bukan sekedar persetubuhan antara jenis kelamin yang berbeda. Sebagai makhluk yang disempurnakan Allah swt., maka perkawinan mempunyai tujuan untuk membentuk keluarga yang bahagia dan kekal. Olehnya itu, Islam memandang bahwa perkawinan merupakan basis yang baik dilakukan bagi masyarakat karena perkawinan merupakan ikatan lahir batin yang sah dan merupakan perjanjian yang mana hukum adat juga berperan serta dalam penyelesaian masalahmasalah perkawinan seperti halnnya pernikahan dini atas latar belakang yang tidak lazim menurut hukum adat hingga hal ini adat menjadikan hukum untuk mengawinkan secara mendesak oleh aparat desa yang itu mengacu kepada kesepakatan masyarakat yang tidak lepas dari unsur agama Islam.

Mengawinkan anak di bawah umur yang begitu mendesak memang penting untuk dilakukan sebagai tindakan penyelamatan terhadap nasib seorang anak yang akan menikah, tetapi jangan sampai mengabaikan syarat yang seharusnya dipenuhi untuk melangsungkan perkawinan. Salah satu strategi pemerintah dalam menjamin 
keabsahan perkawinan dibawah umru yang terlanjur terjadi adalah dengan memberikan kesempatan kepada masyarakat yang akan menikah untuk melakukan dispensasi nikah di Pengadilan Agama, agar legalitas perkawinan menjadi jelas.

Meskipun terbuka lebar jalan untuk melakukan dispensasi nikah pada perkawinan di bawah umur nyatanya di Kabupaten Gorontalo dispensasi nikah yang dilakukan lebih banyak terjadi setelah perkawinan selesai, bahkan ada yang setelah lahirnya anak pertama dalam perkawinan tersebut. Dalam proses dispensasi nikah di Pengadilan Agama memang tidak semua dapat diterima untuk diberikan dispensasi nikah terdapat pula anak yang justru tidak mendapatkan izin dispensasi nikah dari Pengadilan Agama.

Penolakan dispensasi nikah di Pengadilan Agama atau tidak dikabulkannya permohonan dispensasi nikah akan memberikan dampak buruk pada kelangsungan hubungan rumah tangga, ketidaknyamanan dalam rumah tangga kemungkinan besar akan terjadi. Oleh sebab itu, janganlah melakukan penundaan proses dispensasi nikah jika perkawinan memang sudah akan dilaksanakan, lebih baik menunda perkawinan daripada harus menunda pelaksanaan dispensasi. Sebab perkawinan tidak akan berarti apa-apa jika akhirnya tetap tidak tercatat secara sah di KUA.

\section{Pengulangan Akad Nikah}

Akad nikah dapat dikatakan sah apabila terpenuhi syarat dan rukun nikah yang telah ditentukan dan apabila diucapkan dengan perkataaan yang menunjukkan akad pernikahan dengan bahasa yang dipahami oleh kedua belah pihak. Oleh karena itu, dalam melaksanakan ijab dan qabul harus menggunakan kata-kata yang dapat dipahami oleh masing-masing pihak yang melangsungkan akad nikah sebagai pernyataan kemauan yang timbul dari kedua belah pihak, dan tidak boleh menggunakan kata-kata yang samar atau tidak dimengerti oleh kedua belah pihak maksudnya.

Kelalaian pencatatan nikah pada perkawinan di bawah umur seperti apa yang terjadi di Kabupaten Gorontalo dapat berakibat hukum pada pengulangan akad nikah jika ternyata pada proses akad nikah yang pertama tidak dilakukan pencatatan nikah. Setelah proses akad nikah yang pertama meskipun secara agama dianggap sah tetapi 
karena tidak adanya pencatatan perkawinan maka KUA akan kembali melakukan akad nikah pada saat terpenuhi syarat pencatatan nikah.

Pencatatan perkawinan pada hakikatnya bertujuan untuk memberikan kepastian dan perlindungan hukum bagi pasangan suami istri, termasuk kepastian dan perlindungan hukum terhadap akibat yang ditimbulkan dari perkawinan itu sendiri, yaitu tentang hak dan kewajiban masing-masing secara timbal balik, tentang anakanak yang dilahirkan, dan hak-hak anak berupa warisan dari orang tuanya kelak, dan juga akibat dari legalitas perkawinan yang tidak dapat diakui. Pemerintah mengatur pencatatan perkawinan adalah sesuai dengan epistemologi hukum Islam dengan metode istishlah atau maslahat.

Begitu ketatnya aturan pencatatan nikah yang telah ada sejak dahulu, sebagai wujud nyata hadirnya pemerintah dalam memberikan perlindungan pada peristiwa perkawinan yang terjadi di masyarakat. Sayangnya memang proses ini tidak digunakan dengan baik oleh sebagian masyarakat yang enggan atau lalai mencatatkan perkawinannya, sebagai akibat hukumnya tidak dilakukan pencatatan perkawinan akad nikah yang sebelumnya dapat dianggap tidak sah dan kembali dilakukan akad nikah.

\section{Perkawinan Tanpa Kehadiran Aparat Pemerintah}

Ketiadaan sanksi yang berat terhadap pelanggaran pencatatan perkawinan dapat mengakibatkan banyaknya pelanggaran yang dilakukan di masyarakat Indonesia. Saknsi yang ada jika terjadi pelanggaran pencatatan perkawinan khususnya di masyarakat Kabupaten Gorontalo hanya berupa tidak menghadiri perkawinan yang dilakukan dengan tidak tercatat, sanksi ini tidak hanya dilakukan oleh pihak pencatatan nikah (KUA) tetapi juga dilakukan oleh pemerintah Desa yang mewilayahi pelaksanaan perkawinan tersebut.

Perkawinan Tanpa Kehadiran Aparat Pemerintah banyak dilakukan di masyarakat Kabupaten Gorontalo, biasanya hal ini terjadi akibat dari pemahaman masyarakat terhadap persoalan perkawinan sangat rendah. Masyarakat lebih mementingkan pelaksanaan pesta perkawinannya, merencanakan terlebih dahulu dan melaksanakan proses awal persiapan perkawinan sampai dengan penentuan tanggal perkawinan tanpa koordinasi dengan pihak berwenang, setelah hari pelaksanaan 
perkawinan ditentukan barulah mereka mendaftarkan perkawinannya yang pada akhirnya mendapatkan penolakan dari KUA karena tidak memenuhi syarat untuk melangsungkan perkawinan. Akibat dari penolakan inilah masyarakat memilih untuk mengabaikan pencatatan perkawinan dan memilih untuk melanjutkan proses yang telah direncanakan sebelumnya, sehingga terjadilah perkawinan yang tidak tercatat yang nantinya akan tidak dihadiri oleh petugas yang berwenang baik dari KUA maupun dari pemerintah desa.

\section{E. Kesimpulan}

Bentuk kelalaian pencatatan nikah pada perkawinan dibawah umur di Kabupaten Gorontalo, berdasarkan hasil penelitian terdapat beberapa bentuk kelalaian yang dilakukan antara lain: Pertama, adanya kelalaian orang tua; kelalaian orang tua dalam pencatatan perkawinan anak di bawah umur antara lain: tidak melaporkan perkawinan anaknya ke pihak berwenang, yaitu PPN, ketidaktahuan prosedur pencatatan nikah, alasan perkawinan sudah mendesak untuk dilaksanakan, dan yang terakhir adalah tidak adanya persetujuan orang tua untuk menikahkan anaknya, sehingga terjadilah kelalaian orang tua dalam pencatatan perkawinan di bawah umur; Kedua, adanya kelalaian anak; kelalaian pencatatan perkawinan juga dilakukan oleh anak itu sendiri yang sebelum terjadi perkawinan telah bermasalah dalam hal ini telah hamil di luar nikah, sehingga banyak anak yang tidak mencatatkan perkawinannya karena desakan perkawinan yang sudah harus dilakukan sementara jika harus mengikuti prosedur pencatatan perkawinan maka akan semakin lama prosesnya dan dikhawatirkan anak akan terlebih dahulu lahir; Ketiga, adanya kelalaian PPN; kelalaian yang sering dilakukan oleh PPN adalah berkas administrasi pencatatan nikah tidak sampai di meja PPN, hal ini biasanya dilakukan oleh Pembantu PPN yang ada di desa terutama desa terpencil yang jangkauannya cukup jauh ke KUA, sehingga terkadang masyarakat telah mempercayakan kepadanya untuk pencatatan perkawinan tetapi setelah perkawinan selesai buku nikah tidak keluar karena keterlambatan memasukkan berkas persyaratan pencatatan nikah, selain itu juga berdasarkan hasil penelitian yang telah dilakukan juga ada PPN yang ternyata keliru dalam pencatatan nikah yang tidak 
Kelalaian Pencatatan Nikah Pada Perkawinan di Bawah Umur di Kabupaten Gorontalo

mengetahui bahwa pasangan calon pengantin salah satunya belum cukup umur, sehingga pencatatan perkawinan dibatalkan dan ditunda sampai dengan menunggu umur pengantin cukup untuk menikah.

Akibat hukum terhadap kelalaian pencatatan nikah pada perkawinan di bawah umur di Kabupaten Gorontalo, yaitu: Pertama, legalitas anak hasil perkawinan, anak hasil perkawinan di bawah umur yang tidak dicatatkan atau terlambat untuk mencatatkan perkawinannya berdampak pada kesulitan untuk mendapatkan akta kelahiran anak karena syarat untuk mendapatkan akta kelahiran haruslah ada buku nikah orang tua, kalaupun akta kelahiran anak bisa didapatkan namun hanya dapat dicantumkan sebagai anak ibu dan tidak mencantumkan nama ayah pada akta kelahirannya, bahkan ada pula yang justru mengalihkan anaknya menjadi anak orang tua dan masuk dalam Kartu Keluarga orang tua demi untuk mendapatkan legalitas anak hasil perkawinan dibawah umur; Kedua, mudah terjadi perpisahan (perceraian), perkawinan yang tidak memiliki bukti otentik seperti buku nikah maka rentan dengan persoalan perpisahan atau perceraian seperti apa yang terjadi di Kabupaten Gorontalo, sebab salah satu diantaranya akan mudah untuk meninggalkan pasangannya karena tidak dapat dituntut secara hukum terhadap tanggung jawabnya sebagai suami/istri; Ketiga, penolakan dispensasi nikah, penolakan ini dilakukan oleh Pengadilan Agama yang berwenang memeriksa perkaranya, biasanya penolakan itu dilakukan akibat dari kelalaian pihak itu sendiri, seperti melakukan dispensasi nikah setelah terjadinya perkawinan, tidak terpenuhi syarat dispensasi nikah seperti yang mengajukan harusnya orang tua bukan anak itu sendiri dan lain sebagainya; Keempat, pengulangan akad nikah; bagi anak di bawah umur yang terlambat mencatatkan perkawinan maka pihak KUA tidak membenarkan lagi adanya pencatatan perkawinan yang dilakukan mundur disesuaikan dengan perkawinan awal yang terjadi, yang ada perkawinan akan dilakukan seperti baru lagi dengan melakukan kembali akad nikah dan dicatat sesuai dengan tanggal akad nikah kedua; dan Kelima, perkawinan tanpa kehadiran pemerintah terkait, hal ini sebagai sanksi bagi masyarakat khususnya yang ada di Kabupaten Gorontalo dalam rangka memperkecil terjadinya perkawinan tidak tercatat, dengan tidak hadirnya aparat pemerintah maka perkawinan itu dianggap tidak memenuhi syarat perkawinan, 
walaupun begitu perkawinan seperti ini masih saja terjadi dan sanksi yang diterapkan terkadang dianggap terlalu ringan.

\section{Daftar Pustaka}

Ali, Zainudin. Hukum Perdata Islam di Indonesia. Jakarta: Sinar Grafika, 2006.

Departemen Agama RI. Tuntunan Keluarga Sakinah Bagi Remaja Usia Nikah (Seri Psikologi). Direktorat Jenderal Bimas Islam Direktorat Urais dan Pembinaan Syariah : Jakarta Tahun 2007.

Kementerian Agama RI. Ummul Mukminin: Al-Qur'an dan Terjemah untuk Wanita. Jakarta: Penerbit Wali, 2010.

Republik Indonesia. Instruksi Presiden Nomor 1 Tahun 1991 tentang Penyebarluasan Kompilasi Hukum Islam.

Republik Indonesia. Undang-Undang Nomor 1 Tahun 1974 tentang Perkawinan

Republik Indonesia. Undang-Undang Nomor 16 Tahun 2019 tentang Perubahan Atas Undang-Undang Nomor 1 Tahun 1974 tentang Perkawinan.

Republik Indonesia. Undang-Undang Nomor 22 Tahun 1946 tentang Pencatatan Nikah, Talak dan Rujuk.

Republik Indonesia. Undang-Undang Nomor 23 Tahun 2006 tentang Administrasi Kependudukan.

Republik Indonesia. Undang-Undang Nomor 32 Tahun 1954 tentang Penetapan Berlakunya Undang-Undang Republik Indonesia Tanggal 21 Nopember 1946 No. 22 Tahun 1946 tentang Pencatatan Nikah, Talak dan Rujuk di Seluruh Daerah Luar Jawa dan Madura.

Rifdan dan Muhammadong, Tata Kelola Pencatatan Perkawinan Berdasarkan UndangUndang. Makassar: Badan Penerbit UNM, 2017.

Rofiq, Ahmad. Hukum Islam di Indonesia. Jakarta: PT Raja Grafindo Persada, 1995. Hukum Perdata Islam di Indonesia. Jakarta: PT. Raja Grafindo Persada, 2013.

Sastroatmodjo Arso, dan Awasit Aulawi. Hukum Perkawinan Indonesia. Jakarta: Bulan Bintang, 1978.

Shihab, M. Quraish. Tafsir al-Misbah. Jakarta: Lentera Hati, 2004. 
Kelalaian Pencatatan Nikah Pada Perkawinan di Bawah Umur di Kabupaten Gorontalo

Al-Syarthawi, Muhammad Ali. Syarh Qanun al-Ahwal al-Syakhshiyah. Amman: Dar alFiqr, 1997.

Tim Perumus. Pohutu Aadati Lo Hulondalo Tata Upacara Adat Gorontalo, Hasil Seminar Adat Gorontalo 2007. Gorontalo: Pemerintah Daerah Kabupaten Gorontalo, Forum Pengkajian Islam Al-Kautsar Gorontalo, Tokoh Adat U Duluwo Limo Lo Pohalaa Gorontalo dan Tim Akademisi Gorontalo, 2008.

Uqlah, Muhammad. Nidham al-Usrah fi al-Islam. Juz I. Amman: Maktabah al-Risalah al-Haditsah, 1989.

Yusdani. Menuju Fiqh Keluarga Progresif. Yogyakarta: Kaukaba Dipantara, 2015.

https://asy79aulia.wordpress.com/2012/12/28/pencatatanperkawinan-sebuah-tinjauanyuridis-menurut-hukum-islam-dan-undang-undang-nomor-1-tahun-1974/ 